\title{
Money demand instability and money supply in Tunisia during transition period
}

\author{
Olfa Manai Daboussi ${ }^{1}$, Amira Majoul $^{2}$ \\ ${ }^{1}$ MASE- ESSAI and MACMA- TUNIS, Higher Institute of Management of Tunis, University of Tunis, Tunisia \\ ${ }^{2}$ Applied Quantitative Analysis Unit (UAQUAP) -Tunisia ISG and GATE (UMR 5824CNRS), Higher Institute of Management of Tunis, \\ University of Tunis, Tunisia
}

Email address:

manaolfa@yahoo.com (O. M. Daboussi),majoul_amira@hotmail.com (A. Majoul)

\section{To cite this article:}

Olfa Manai Daboussi, Amira Majoul. Money Demand Instability and Money Supply in Tunisia during Transition Period. Journal of World Economic Research. Special Issue: Issues and Challenges of the Financial and Economic Crisis Throughout the World.

Vol. 3, No. 6-1, 2014, pp. 15-21. doi: 10.11648/j.jwer.s.2014030601.13

\begin{abstract}
The objective of this paper is to present an empirical analysis of Tunisian money demand, money supply and monetary policy before and after economic transitions. This work explores the instability in estimated money demand functions. We evaluate the role of financial innovations in stabilizing the demand money function over two periods. Results suggest that the monetary aggregate has become inadequate to justify the controllability of money supply by the Tunisian Central Bank during the period of 1987 to 2013. The empirical evidence presented in the paper, provides that Tunisia to be held account of the effect of financial liberalization for adopting the inflation targeting like alternative monetary strategy.
\end{abstract}

Keywords: Monetary Aggregates, Monetary Policy, Time Series, Tunisia

\section{Introduction}

Since 1987 , the monetary policy of Tunisia has undergone considerable changes. The objective of monetary policy is to give up the direct and discretionary regulation and replace it with one that is based on the determination of a final objective of price stability. Prior to 1986 , the failure of the direct regulation has been materialized of the one part by the disproportionate development of money compared to the domestic product growth and other hand by inefficiency in the allocation of monetary resources. The instability of the demand for money has received enormous academic attention because an understanding of its causes and consequences can inform the setting of monetary policy.

From now on, the Tunisian Central Bank lays down its objective on the quantitative control of the evolution of the monetary aggregates and it insists on the variation of the aggregates which is proportional with GDP. This choice aims to direct anticipations of the economic agents in order to maintain the rate of inflation on a level compared to with that observed in the competitor and partners countries and to reinforce the credibility of the Central Bank. At the time of financial liberalization, the intermediate target is likely to fail because of the difficulty in controlling the money supply due to changes in the behavior of economic agents in respect of the holding of liquidity. A large number of industrialized country case studies show that the demand for money has become unstable due to financial reforms (McPhail (1991), Haug (1999), Maki and Kitasaka (2006), Caporale and GilAlana (2005) and Haug (2006). The financial market reforms and liberalization in developing countries may have contributed to instability in their own money demand functions.

In this work, we will carry out an empirical investigation relating to the estimate the money demand function and money supply within the framework of the Tunisian monetary policy.

Our objective is to check the degree of effectiveness of the monetary targeting in Tunisia. At the same time we will present the limits of the adoption of this policy in order to find an alternative solution to pass to another policy of inflation target stricter than the first. This in order to answer the following problems: If the monetary targeting is a strategy excessively used in the industrialized countries and it were abandoned at the time of the financial innovation, why Tunisia is still adopting it?

During these last decades, the Tunisian conduct of monetary policy has known several changes and transformations following the installation of a plan of 
structural adjustment. Within this framework, it is of such importance to show the role of the monetary targeting adopted in the conduct of the monetary policy.

Initially, we will present a synthesis of some empirical work on the application of the intermediate mechanism of the monetary targeting. One resorts in the second place to a representation and a checking of the application of the monetary targeting through the study of the stability of money demand function and the controllability of the supply money. We will try to synthesize certain empirical work which treated the relationship with the monetary aggregates, inflation and the level of the income. The majority of empirical work showed that the monetary targeting is confirmed by the existence of a relation of long term between the money and inflation. As well as the controllability of the monetary aggregates by the Central Bank brings to the good management of this strategy and its success. Then, we test empirically the Stability of money demand function and the controllability of the supply money at the time of financial liberalization in Tunisia. The paper is organized as follows: Section 2 presents the results that underlined the stability and controllability in monetary target policy. Section 3 provides the Theoretical framework Section 4 presents the empirical investigation relative to Tunisian case. Finally section 5 concluded the paper.

\section{Stability and Controllability}

\subsection{Stability of the Money Demand Function}

Milton Friedman is the first which has a modern argument in favor of the rules in its quantity theory of money. According to this theory, to avoid inflation, it is necessary to control the money supply and to stabilize it around its tendency in long term. He considers that this theory is satisfactory to understand the inflationary phenomenon. Therefore, the intermediate target is a monetary mode appropriate to the monetarists. Thus it is regarded as a solution to handle the instruments of the monetary policy and to carry out the final objective of price stability. In fact, the Central Bank seeks to control inflation according to intermediate objectives related to the monetary growth. The changing of the behaviors of agents with regard to the liquidity was justified by the diversity of their placements with raised profitability, which changed the money demand function and could make it even unstable. Whether money demand is stable is an empirical question that provides important insight for theory and policy making.

Several works was carried out during specific economic transitional periods and which are based on the study of the stability of the demand function of money (Teriba (1974), Darrat (1986), Arize et al. (1990), Adam (1992), Kallon (1992), Simmons (1992), Fielding (1994), Ghartey (1998), Nachega (2001), Anoruo (2002), Nwaobi (2002), Nell (2003), Sterken (2004), Akinlo (2006), Nwafor et al. (2007), Owoye and Onafowora (2007), Bahmani-Oskooee and Gelan (2009) and Drama and Yao (2010)).
This demand function of money is related to long period, as Friedman affirms it, and stable according to its components. The permanent income changes moderately over time, the price level fluctuates around the level and interest rate is only one average rate. These characteristics make the demand function stable and constant evidenced by the constancy of the velocity of money. Moreover, the empirical tests carried out by the work of Friedman and Schwartz (1963), on the study of the demand function of money in the United States during 1867 to 1960 , show that the money velocity falls compared to the income. This variability the money velocity is influenced by the role of the interest rate which can be regarded as auxiliary in the variation of demand function of money. Within the same empirical framework, Friedman and Schwartz tested the causal relationship between the money and prices to show that inflation is of monetary origin. The results obtained show that the fluctuation of the stock of money evolves in opposite direction with the money velocity and that the long movements of the prices are explained by the impact of the variation and the evolution of the stock of money.

According to an empirical study undertaken on the seven OECD countries, Blundel-wignall and al (1990) showed that the relation of co-integration between the monetary aggregates and the income does not exist. These results prove that the impact of the financial innovations has changed the structure of the aggregates opposite the mode of the investments and their profitability except for the United States and Germany. Friedman (1988) shows, during one advanced period, that the relation between money and income does not exist for the case of the United States during 1979 to 1982 . Even the use of another aggregate M2 or M3 still shows the absence on the one hand relation on the longrun between money and income and on the other hand between credit and monetary aggregates. In the same framework, Darrat (1986) carries out an empirical examination according the procedures suggested by Sargent (1976). In the MENA countries (Tunisia, Morocco, Algeria and Libya), for the $1960-19801$, the relation between money-price is unidirectional. These results are consistent with those obtained by the monetarists and they concluded that the money causes inflation.

\subsection{Controllability of the Money Supply}

The controllability of the money is a necessary condition for the success of the monetary aggregates policy. The Central Bank uses its capacity to control the monetary aggregate. In fact, the target monetary aggregate must be well controlled by the Central Bank. The controllability will be necessary: First, to maintain the relationship between the monetary aggregate and the money supply stable 2 and predictable, second to regulate the liquidity in the economy. In accordance with the supply theory of money, Brunner and Meltzer (1967) show that the fluctuations of the economic

1 With quarterly data.

2 The money multiplier is stable. 
situation, characterized by variation of the interest rate, the inflation rate and income, can be at the origin of the irregularity of the money multiplier. This concept of the money multiplier was developed by the monetarists. It is responsible for justifying the relation between the monetary aggregate and money base (B).

Since the ending of 1986, Tunisia has been undertaking financial and macroeconomic reforms. These structural reforms aimed mainly at liberalizing interest rates, introducing new financial and flexible instruments for the conduct of monetary policy. To make sure that the monetary stability objective is reached, monetary authorities adopted a monetary targeting strategy. The operating objective is changed and the interest rate has been deregulated since 1987. Interest rates of short and long term have been liberalized. Central Bank of Tunisia fixed these rates on credit granted to so-called priority sectors, such as agriculture. The monetary targeting strategy of the Central Bank of Tunisia assigned a prominent role to money growth. It has pursued at setting of a growth standard of monetary aggregate M2 as an internal intermediary objective. The monetary authority can control a portion of changes in the money supply by controlling the size of changes in money base. Therefore, reform was needed to regain control and contain inflationary pressures. A great number of empirical studies (Brunner and Meltzer, 1967; Trichel, 1997) focused on the controllability aspect and they concluded that it exist a relationship between the money supply and the monetary base. In the others recent papers, Friedman and Kutner (1993) neglected the controllability condition. Estrella and Mishkin (1997) affirm that the use of monetary aggregates in policy is feasible only if the relationships between money and income or prices are both strong and stable over time. The analysis in the case of Tunisia, during the period 1978-1990, Najeh and Bouaziz (1990) show that money aggregate $\mathrm{M}_{2}$ is not controllable. In the other study during 1971-1989, Najeh and Kria (1990) show that the demand functions of money is unstable at time of the financial liberalization. In this respect, the theory of money supply endogeneity is a relatively new theory, since the empirical works examining money supply endogeneity only started in the early 1980s (Moore (1983; 1988)). Money supply endogeneity evidence was confirmed by Yulia (2005), using the Russian data. However, different from previous studies (monetarist view), Yulia found that inflation leads to money supply growth. Such findings support the endogenous money supply view. Lavoie (2005) examined the monetary based endogeneity of the Canadian economy. His findings suggest that asset-based financial system, just like credit in financial systems, rely on a fully endogenous supply of highpowered money, with central bank engaging essentially in "defensive" operations. Our aim in this paper is: first, show the robustness of the Tunisian monetary policy to reach its objectives of price stability and keeping the inflation rate at a level close to that found in the countries of trading partners and competitors. Second, gives to literature an idea on opportunities of Tunisian Central Bank to adopt an alternative inflation targeting policy like many industrial or emerging countries.

\section{Theoretical Framework}

\subsection{The Model}

Our approach consists in investigating empirically the stability and the controllability of demand and supply function of money. We use simple econometric technique estimation, based on quarterly time-series, by Ordinary Least Squares (OLS) regression to assess the link between money aggregate, inflation, income; in the other hand, $\mathrm{M}_{2}$ aggregate, money base and credit. This method is also in accordance with the inside money model of monetarists 3 were the demand function of money can be written as follows:

$$
\operatorname{Ln} \mathrm{m}_{\mathrm{t}}^{\mathrm{d}}=\theta+\alpha \operatorname{Ln} \mathrm{y}_{\mathrm{t}}+\beta \pi_{\mathrm{t}}+\xi_{\mathrm{t}}
$$

The traditional work used in the literature the monetary aggregate variable employed is the broad money $\mathrm{M}_{2}$ to the level of price level $\left(\mathrm{m}_{\mathrm{t}}^{\mathrm{d}}=\mathrm{M}_{2 \mathrm{t}} / \mathrm{P}_{\mathrm{t}}\right) . \mathrm{M}_{2}$ is the sum of the narrow money and quasi-money. The price variable is the consumer price index. $\mathrm{y}_{\mathrm{t}}$ and $\pi_{\mathrm{t}}$ are respectively the real GDP and the rate of inflation of the same time t. $\xi_{t}$ indicates the error term, $\theta$ is a constant.

To test the controllability of money aggregate, the relationship between $\mathrm{M}_{2}$ aggregate and money base is represented by the following equation:

$$
\operatorname{Ln} \mathrm{M}_{2}=\mathrm{C}+\gamma \operatorname{Ln} \mathrm{B}+\delta \operatorname{Ln} \mathrm{CRD}+\zeta_{\mathrm{t}}
$$

$\mathrm{M}_{2}$ and $\mathrm{B}$ are respectively, money aggregate and money base: it's equal to currency and reserves held by commercial banks. CRD is a credit: it concerns loans which are granted by the deposit banks to the economy over their ordinary resources.

\subsection{Variables and Data}

For testing the demand function of money, the quarterly data used cover the first period (1967: Q1 to 1986: Q2) and the second period (1987: Q1 to 2013: Q4).The first period corresponds to the period before the monetary regulation. The second period is after regulation and is at the time of the financial liberalization. For testing the supply function of money, the quarterly data used cover the first period (1975: Q1 to 1986: Q2) and the second period (1987: Q1 to 2013: Q4). Some years are dropped because of the lack of data on the variable credit. All variables are in logs. Data sources are the International Financial Statistics of the International Monetary Fund, the Word Development Indicators of the Word Bank and the Statistics of the Central Bank of Tunisia.

\section{Empirical Investigation}

In the preliminary step, the paper proceeds to check whether each variable is stationary or not. The tests for unit

3 Friedman (1968), for case of USA during 1867-1960. 
roots are using Dickey-Fuller and Phillips-Perrons. In table 1 (See appendix), the results point out that all the variables are integrated of order I (1) and for different sample periods. Table 2, reports the results of the tests using the (OLS) regression for the determination of the stability of the demand function money. In this equation money aggregate is dependent variable.

Table 2. Estimation of demand function of money

\begin{tabular}{|c|c|c|}
\hline \multicolumn{3}{|c|}{ The demand function of money: 1967- 1986} \\
\hline \multicolumn{3}{|c|}{ Dependent Variable: $\operatorname{Ln}\left(\mathrm{m}_{\mathrm{t}}{ }^{\mathrm{d}}\right)$} \\
\hline Variables & Coefficients & t -Student \\
\hline Constant & -32.63 & -21.78 \\
\hline $\operatorname{Ln} y_{t}$ & 4. 67 & 23.76 \\
\hline$\pi_{\mathrm{t}}$ & 0.07 & 1.63 \\
\hline R- Squared $\left(\mathrm{R}^{2}\right)$ & 0.86 & \\
\hline Adjusted R - Squared & 0.85 & \\
\hline Durbin Watson & 2.7 & \\
\hline Number of observations & 76 & \\
\hline \multicolumn{3}{|c|}{ The demand function of money: 1987- 2013} \\
\hline \multicolumn{3}{|c|}{ Dependent Variable: $\operatorname{Ln}\left(\mathrm{m}_{\mathrm{t}}{ }^{\mathrm{d}}\right)$} \\
\hline Variables & Coefficients & t-Student \\
\hline Constant & -1.43 & -1.03 \\
\hline $\operatorname{Ln} y_{t}$ & -1.69 & -1.94 \\
\hline$\pi_{\mathrm{t}}$ & 0.86 & 1.98 \\
\hline R- Squared $\left(\mathrm{R}^{2}\right)$ & 0.46 & \\
\hline Adjusted R - Squared & 0.49 & \\
\hline Durbin Watson & 0.84 & \\
\hline Number of observations & 104 & \\
\hline
\end{tabular}

The results show that there is a positive relationship between money and inflation over the period before reforms but link between those variable is statistically no significant ( $\mathrm{t}$-Statistic $=1.63)$. The significance of the adjusted $\mathrm{R}^{2}$ (Adjusted $\mathrm{R}=0.85$ ) is assumed to be due to fluctuations in income; when the income rises, inflation rate increases. In addition, these results can explain the stability of the demand function of money.

By contrast, during the post-reforms period the reliable linkage between money and prices can provide evidence on the validity of the monetarist hypothesis. The results show that the size significance of the adjusted $\mathrm{R}^{2}$ is almost for $50 \%$ and it have a weak magnitude.

Note that equation (2) estimation implies that the fluctuation in $\mathrm{M}_{2}$ aggregate provides a sensitive relationship between the inflation rate and the goal of monetary policy. Nevertheless, this moderate of the adjusted $\mathrm{R}^{2}$ argued that the demand function of money is unstable over the postmonetary regulation period. In both results, money plays a central role in explaining the behavior of prices, eventually, over a transition period the price stability represents a fundamental goal of the monetary policy. In the other hand, the money supply growth has no significant impact upon income, this relationship cannot be considered as reliable for monetary targeting strategy (see fig. A (a)). According to the above estimation results, moderate of the coefficients of the exogenous variables provided that it is a change structural affecting the demand function of money. The instability of this function is explained by the change of the behaviors of the economic agents with regard to the currency following the appearance of the new financial products. These findings are supported by the studies of Freidman who investigated the instability of the demand money function at the time of financial liberalization.

Table 3, reports the results of the tests using the (OLS) procedure for the determination of the controllability of the money supply. In this equation $\mathrm{M}_{2}$ aggregate is dependent variable.

According to the above estimation results during (1975: Q1 to 1986: Q2), the correlation is measured by the adjusted $\mathrm{R}^{2}$ statistics of 0 means that variation in monetary base (B) accounts for none of the $\mathrm{M}_{2}$ aggregate. Before reforms, the statistical association between money aggregate $\left(\mathrm{M}_{2}\right)$ and money base is explains by (t-Statistic $=1.610)$ and the money base (B) explains about $50 \%$ of the total of variation in the money aggregate $\left(\mathrm{M}_{2}\right)$. On the other hand after 1986, the empirical results show that the significance of the adjusted $\mathrm{R}^{2}$ can be argued that the variation in the money aggregate $\left(\mathrm{M}_{2}\right)$ provides a sensitive relationship between money supply and money base (B). The elasticity of the money base is moderate, the monetary base (B) explains about $80 \%$ of the total of variation in the money aggregate $\left(\mathrm{M}_{2}\right)$. We can conclude that the money aggregate $\left(\mathrm{M}_{2}\right)$ is controllable since 1987 .

The regression show that a base regime would be a feasible operating regime for the control of the money supply and Central Bank of Tunisia derive a volume of the injection of High-Powered money consistent with the monetary targeting strategy.

Table 3 , shows that a $1 \%$ increase in bank lending (CRD) leads to a $0.87 \%$ increase in $\mathrm{M}_{2}$ aggregate but during the two periods of estimation the link between $(\mathrm{CRD})$ and $\left(\mathrm{M}_{2}\right)$ is not statistically significant. These tests show that link from credit bank towards money supply emphasizes the endogenous of money supply and the evolution of the credit is not often tributary with the evolution of the money supply (see fig. A (b)).

Table 3. Estimation of supply function of money

\begin{tabular}{lll}
\hline \multicolumn{3}{l}{ The supply function of money: $\mathbf{1 9 7 5}-\mathbf{1 9 8 6}$} \\
\hline Dependent Variable: $\mathbf{L n M}_{\mathbf{2}}$ & \multicolumn{1}{l}{ Coefficients } & t -Student \\
\hline Variables & 0.55 & 2.25 \\
\hline Constant & 0.14 & 1.61 \\
Ln B & 0.032 & 0.16 \\
Ln CRD & 0.57 & \\
R- Squared (R $\left.{ }^{2}\right)$ & 0.51 & \\
Adjusted R - Squared & 1.32 & \\
Durbin Watson & 44 & \\
Number of observations & $1987-2013$ & \\
The supply function of money: & \\
Dependent Variable: LnM & \\
Variables & & 0.56 \\
Constant & Coefficients & 2.84 \\
Ln B & 15.08 & 1.96 \\
Ln CRD & 1.29 & \\
R- Squared (R ${ }^{2}$ ) & 0.87 & \\
Adjusted R - Squared & 0.77 & \\
Durbin Watson & 0.79 & \\
Number of observations & 1.97 & \\
\hline
\end{tabular}


These findings are consistent with those of Howells and Hussein (1998) and Friedman (1988).

Indeed, these empirical results during the monetary period of regulation remains without any doubt related on the movements of financial liberalization, the reliable role of the monetary authorities and the functional role of the Tunisian Central Bank on the money market. The $\mathrm{M}_{2}$ aggregate progressed more quickly than credit bank. This is explained by an amounts of liquidity is distributed by Central Bank of Tunisia through the refinancing the priority sectors. We can deduce that $\mathrm{M}_{2}$ aggregate is not an appropriate intermediary target for the Tunisian Central Bank and the quantity of central money is not totally controllable.

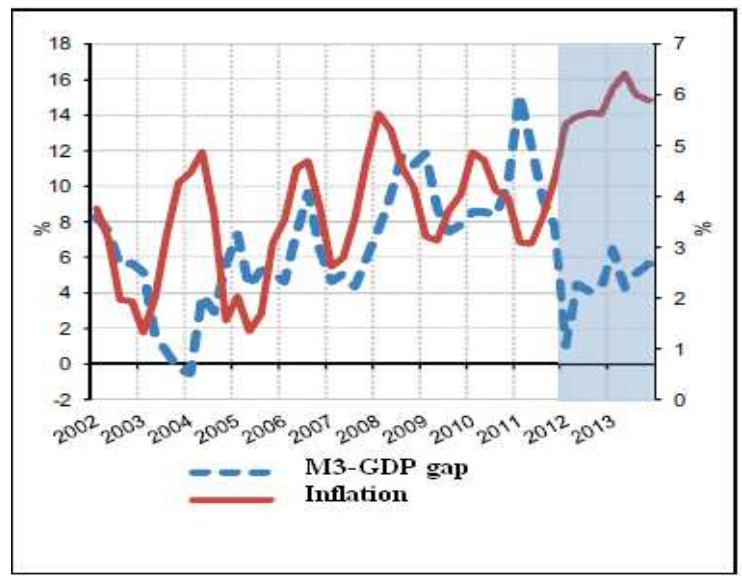

(a) Evolution of M3- GDP gap and inflation

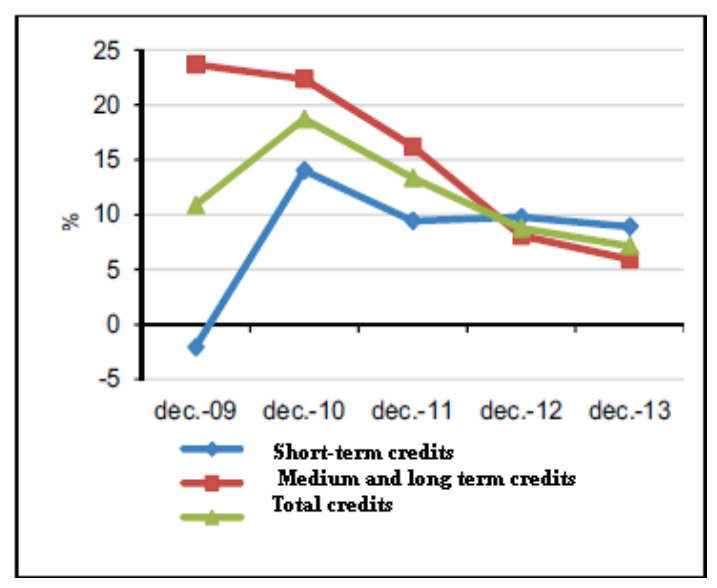

(b) Evolution of the total credits

Source: Annual report of BCT- Tunisia-2013.

Fig. A.

\section{Conclusion}

This paper has examined empirically the instability of the demand function of money over the period before and after transition. Equation (1) allows us to see the effect that the quantity of money has on the economy. From this analysis, we justify that $M_{2}$ aggregates is not more controllable in this last period of time in Tunisia. We tried to show the impact of the financial innovations on the structure of the monetary aggregates in Tunisia. The monetary authorities succeeded in slowing down the acceleration of inflation and envisaging the variables to know the inflation rate, $\mathrm{M}_{2}$ aggregates and the money velocity. Thus, the relation between money supply and base are proven by the intermediary of the multiplier. This last is adopted by the Tunisian Central Bank whose objective is to control the credits.

This indicator does not cease becoming unstable at the time of financial liberalization and following the changes of the behaviors of the economic agents towards detention of money.

These econometric tools allow us to appraise the prerequisites of the implementation of the monetary target strategy and show us the robust policy implications about the monetary policy of the Central Bank of Tunisia. The empirical analysis relate to the limits of the success of the monetary aggregate target. Therefore, the monetary target can succeed only through some conditions to know controllability and stability. The price stability aim was considered as serious challenges to decrease inflation rate. Monetary authorities tried to find new instruments and reforms to cure this problem. However, monetary targeting has been the main strategy of the current monetary policy. The empirical evidence presented above has important implications for the conduct of monetary policy in Tunisia. Indeed, despite the convenience of results of the study, the Tunisian Central Bank must take into account the fact that the inflation target is a priority over the period of the financial of liberalization and after the period of revolution of 2011. The success of inflation target depends on some institutional and economic conditions it seems currently hard to meet. Tunisia must fulfill a set of these conditions, in the context of our study; Central Bank independence is a fundamental institutional requirement to adjust instruments of monetary policy toward the attainment of the objective of low inflation. Controlling money supply is the main instrument of Tunisian Central Bank. Money control consists in injecting more central bank money according the gap observed within the money market and the target level and the Central bank continues to do so in order to exercise quantitative control on the amount and distribution of total credit in Tunisia (see Manai, O. et al. (2013)).

Our analysis has some limitation. Indeed, our empirical approach cannot detect the long-run relationship between monetary aggregates and the inflation rate. So, it is possible with other techniques to address this question by having recourse to the co-integration theory. Our econometric method cannot detect the short-run dynamics, it may be relevant from the policy perspective to estimate link between variables of equation (1) and (2) with an error correction model. 


\section{Appendix}

Table 1. Unit root tests for the variables in first differences

\begin{tabular}{|c|c|c|c|}
\hline \multicolumn{3}{|c|}{ Tests with constant } & \multirow[b]{2}{*}{ Conclusions } \\
\hline Variables & ADF* & $\mathbf{P P} * *$ & \\
\hline \multicolumn{4}{|c|}{ The demand function of money: $1967-1986$} \\
\hline $\operatorname{Ln~}_{t}{ }^{d}$ & -3.86 & -11.87 & $\mathrm{I}(1)^{\mathrm{o}}$ \\
\hline $\operatorname{Ln} y_{t}$ & -4.94 & -7.71 & $\mathrm{I}(1)^{\mathrm{o}}$ \\
\hline$\pi_{\mathrm{t}}$ & -5.29 & -8.62 & $\mathrm{I}(1)^{\mathrm{o}}$ \\
\hline \multicolumn{4}{|c|}{ The demand function of money: 1987- 2013} \\
\hline $\operatorname{Ln} \mathrm{m}_{\mathrm{t}}{ }^{\mathrm{d}}$ & -7.52 & -11.14 & $\mathrm{I}(1)^{\mathrm{o}}$ \\
\hline $\operatorname{Ln} y_{t}$ & -4.59 & -9.56 & $\mathrm{I}(1)^{\mathrm{o}}$ \\
\hline$\pi_{\mathrm{t}}$ & -5.13 & -8.80 & $\mathrm{I}(1)^{\mathrm{o}}$ \\
\hline At a $5 \%$ level & $(-2.96) \S$ & $(-2.96) \S$ & \\
\hline \multicolumn{4}{|c|}{ Tests with constant } \\
\hline Variables & ADF* & $\mathbf{P P}^{* *}$ & Conclusions \\
\hline \multicolumn{4}{|c|}{ The supply function of money: 1975- 1986} \\
\hline $\operatorname{Ln} \mathrm{M}_{2}$ & -4.79 & -8.83 & $\mathrm{I}(1)^{\mathrm{o}}$ \\
\hline Ln B & -5.76 & -8.45 & $\mathrm{I}(1)^{\mathrm{o}}$ \\
\hline Ln CRD & -8.56 & -10.14 & $\mathrm{I}(1)^{\mathrm{o}}$ \\
\hline \multicolumn{4}{|c|}{ The supply function of money: 1987- 2013} \\
\hline $\mathrm{Ln} \mathrm{M}_{2}$ & -6.58 & -9.89 & $\mathrm{I}(1)^{\mathrm{o}}$ \\
\hline Ln B & -5.39 & -9.49 & $\mathrm{I}(1)^{\mathrm{o}}$ \\
\hline Ln CRD & -7.67 & -13.14 & $\mathrm{I}(1)^{\mathrm{o}}$ \\
\hline At a $5 \%$ level & $(-2.96) \S$ & $(-2.96) \S$ & \\
\hline
\end{tabular}

Notes *Augmented Dickey- Fuller tests, ** Pillips-Perrons tests, $\S$ It denotes that statistical significance, ${ }^{\circ}$ It indicates that variable is integrated on first difference.

JEL Classification: E41, E51, E52.

\section{References}

[1] Blundel-Wignall, A., Browne, F. and Manasse, P. (1990), La Politique Monétaire dans le Contexte de la Libéralisation Financière. Revue Economique de l'OCDE, Vol.15, Nº, pp.163-199.

[2] Borio, C. (2001), Comparing Monetary Policy Operating Procedures across the United States, Japan and the Euro Area. Bank for International Settlements, Monetary and Economic Department, Bis Paper 9.

[3] Boughrara, A. (2007), Can Tunisia Move to Inflation Targeting. The Developing Economies, XLV (1), pp. 27-62.

[4] Brillembour, A. and Khan, M. (1979), The Relationship between Money, Income and Prices: Has Money Mattered Historically?. Journal of Money, Credit and Banking, Vol.11, $\mathrm{N}^{\circ} 3$, pp. 358-365.

[5] Brunner, K. and Meltzer, H. A. (1967), Some Further Investigations on Demand and Supply Function for Money. The Journal of Finance, Vol. 19, pp. 240-283.

[6] Clarida, R., Gali, J. and Gertler, M. (2000), Monetary Policy Rules and Macroeconomic Stability: Evidence and Some Theory. Quarterly Journal of Economics, Mit Press, 115, pp. 147-180.

[7] Darrat, A. (1986), Money, Inflation and Causality in the North African Countries: An Empirical Investigation. Journal of Macroeconomic, Vol.8, $\mathrm{N}^{\circ} 1$, pp. 87-103.

[8] Drama, B. H. G. and Yao, S. (2010) The demand for money in Cote d'Ivoire: evidence from the co-integration test, International Journal of Economics and Finance 3(1).
[9] Ericsson, N. R. and Irons, J. S. (2001), Output and Inflation in the Long Run. Journal of Applied Econometrics, Vol. 16, Nº3, pp. 241- 253.

[10] Estrella, A. and Mishkin, F. (1997), Is There a Role for Monetary Aggregates in the Conduct of Monetary Policy?. Journal of Monetary Economics, Vol.40, ํ2, pp. 279-304.

[11] Friedman, M. (1975), Targets, Instruments and Indicators of Monetary Policy. Journal of Monetary Economics, Vol. 1, pp. 443-473.

[12] Friedman, M. and Schwartz, A. J. (1963), A Monetary History of the United Stated 1867-1960. Princeton University Press 1963.

[13] Friedman, M. (1983), Monetary Policy with a Credit Aggregate Target, NBER Working Paper 0980.

[14] Friedman, M. and Kuttner, K. N. (1993), Another Look at the Evidence on Money-Income Causality. Journal of Econometrics, Vol.57, pp. 189-203.

[15] Friedman, M. (1995), Does Monetary Policy Affect Real Economic Activity: Why do We Still Ask This Question? NBER Working Paper 5212.

[16] Friedman, M. and Kuttner, K. N. (1996), Price Target for US Monetary Policy? Lessons from the Experience with Money Growth Targets. Brookings Paper of Economic Activity, Vol.1, pp. 77-146.

[17] Khan, H. P. and Hussein, K. (1998), The Endogenous of Money Evidence from the G7. Scottish

[18] Journal of Political Economy, Vol.45, N`3, pp. 329-340.

[19] Manai Daboussi, O. (2014). Economic performance and inflation targeting in developing economies. Journal of World Economic Research. 3(1), pp1-7. 
[20] Manai, O. Chebbi, A. Madouri, A. (2013)). Inflation Targeting Policy: Pre-requisites and Opportunities for Tunisia. Science Journal of Economics. pp 1-5.

[21] Moore, B. (1988), The Endogenous Money Supply. Journal of Post Keynesian Economics, Vol.10, N³, pp. 372-385.

[22] Nayan,N., Norsiah, K., Abdullah,M., (2013) Post Keynesian Endogeneity of Money Supply: Panel Evidence. Procedia Economics and Finance. Vol 7, pp 48-54.

[23] Owoye, O. and Onafowora, O. A. (2007), M2 targeting, money demand, and real GDP growth in Nigeria: Do rules apply? Journal of Business and Public Affairs, 1, pp 1-20.
[24] Rao, B. B. and Kumar, S. (2009), A panel data approach to the demand for money and the effects of financial reforms in the Asian countries. Economic Modeling 26, pp 1012-1017.

[25] Sarel, M. (1996), Non Linear Effects of Inflation on Economic Growth .IMF Staff Papers, Vol.43, N¹, pp. 199-215.

[26] Werner, R.A. (2014), Enhanced Debt Management: Solving the Euro-zone crisis by linking debt management with fiscal and monetary policy. Journal of International Money and Finance. Vol 49, Part B, pp 443-469. 